\title{
Ulcerative dermatitis in rats with over fifteen generations of protein malnutrition
}

\author{
By JANINA R. GALLER, * J. G. FOX, J. C. MURPHY \\ AND D. E. MELANSON \\ Department of Nutrition and Food Science, Massachusetts Institute of Technology, Cambridge, \\ Massachusetts 02139, USA
}

(Received 24 August 1978 - Accepted I9 December 1978)

I. Male and female rats with histories of up to twenty generations of protein malnutrition were found to be at a higher risk for the development of ulcerative dermatitis than rats maintained on a low-protein diet for one generation or in controls on an adequate-protein intake.

2. In all groups, female rats were more likely to have dermatitis than male rats.

3. Bacteriologic examination was performed in the intergenerationally malnourished and control animals; Staphylococcus aureus was isolated from the skins of animals in both groups, whether or not any lesion was present. In these two groups of animals, experimental inoculation with $S$. aureus produced dermatitis only in the malnourished animals.

The relationship between malnutrition and infection is felt to be synergistic, in that each condition exacerbates the other (Scrimshaw, 1975). This phenomenon has profound implications for survival, growth, and development in populations at risk from inadequate nutrition.

This report describes the incidence of dermatitis in a colony of rats with histories of many generations of protein malnutrition. Because dermatitis in rodents may result from bacterial, fungal, or parasitic infestation (Von Rooyen, 1936; Oldham, 1967) as well as from nutritional deficiency (Follis, 1958; Jelinck, 1967), affected skin sites were cultured and examined for ectoparasites. Staphylococcus aureus was found on $80 \%$ of the animals afflicted with dermatitis and was experimentally inoculated into test subjects with histories of either protein deficiency or dietary adequacy to determine whether the dermatitis could be reproduced experimentally and whether selective infection would occur in the protein-deficient subjects.

\section{MATERIALS AND METHODS}

\section{Subjects}

Hooded rats descended from a colony of animals with intergenerational malnutrition originated by Dr R. J. C. Stewart at the London School of Tropical Hygiene were used. Experimental animals had been provided with a low-protein diet and well-nourished animals with an adequate protein diet throughout life. More detailed descriptions of the rearing conditions during the first eight generations have been published elsewhere (Payne \& Stewart, 1972; Stewart, 1972). The colony was transferred to the Massachusetts Institute of Technology (MIT) in July 1974, where the treatment was continued. At the time of the first study, the colony included rats that had been malnourished for fourteen to fifteen generations. During the I4-month study conducted at MIT, the colony included I80 rats: thirty-eight males and fifty-five females in the low-protein-diet group and thirty-nine males and forty-eight females in the well-nourished group. At the time of the second study, the colony had reached eighteen generations.

* Also affiliated with the Department of Child Psychiatry and Child Development, Boston University Medical Center, Boston, Massachusetts. 
Table 1. Experimental diet

\begin{tabular}{|c|c|c|}
\hline Ingredient & $\begin{array}{l}\text { Low-protein } \\
\text { diet } \\
\text { (g) }\end{array}$ & $\begin{array}{c}\text { Control } \\
\text { diet } \\
\text { (g) }\end{array}$ \\
\hline Casein & 75 & 250 \\
\hline DL-methionine & I & I \\
\hline Dextrose & 217 & 159 \\
\hline Sucrose & 208 & 153 \\
\hline Dextrin & 235 & 173 \\
\hline Corn oil & 150 & 150 \\
\hline Mineral mix* & 40 & 40 \\
\hline Vitamin mix $\dagger$ & 10 & 10 \\
\hline Vitamin $\mathrm{B}_{12}(1.0 \%$ solution $)$ & 10 & 10 \\
\hline Choline chloride & 4 & 4 \\
\hline Cellulose & 50 & 50 \\
\hline
\end{tabular}

* Rogers-Harper Salt Mix (Rogers \& Harper, 1965).

$\dagger$ The vitamin mixture contained $/ \mathrm{kg}$ : vitamin $\mathrm{K} \mathrm{I} .0 \mathrm{~g}$, thiamine $\mathrm{HCl} 2.0 \mathrm{~g}$, riboflavin $4.0 \mathrm{~g}$, niacin $10.0 \mathrm{~g}$, pyridoxine $\mathrm{HCl} 2.0 \mathrm{~g}$, calcium panthothenate $10.0 \mathrm{~g}$, inositol $40.0 \mathrm{~g}$, ascorbic acid $40.0 \mathrm{~g}$, p-aminobenzoic acid $20.0 \mathrm{~g}, \alpha$-tocopherol $80 \mathrm{mg}$, biotin $100 \mathrm{mg}$, folic acid $400 \mathrm{mg}$, retinol and cholecalciferol $1.84 \mathrm{~g}$, sucrose $868.58 \mathrm{~g}$.

The animals were housed in groups of two or three in galvanized-wire suspension cages. The room was maintained at a temperature of $26-27^{\circ}$ (recorded daily on a Belfort Automatic Thermometer) and a humidity of $40-60 \%$. A reverse $\mathrm{J} 2$-h day-night cycle was provided with continuous illumination from red fluorescent lighting present even during the dark portion of the cycle. All animals were fed ad lib. with either the low-protein diet $(75 \mathrm{~g}$ casein $/ \mathrm{kg})$ or the adequate-protein diet $(250 \mathrm{~g}$ casein $/ \mathrm{kg})$, depending on nutritional history (Table I). Tetracycline (Polyotic; American Cyanamid Co., Princeton, N.J.) was put in the drinking-water $(1 \mathrm{mg} / \mathrm{ml})$ for the year previous to the study because of chronic respiratory disease, which is endemic in the colony.

Two series of observations were made. In the first study, only animals from a lineage that had been fed continuously on the low-protein or the control diet for many generations were considered. During a ro-month period, the incidence of skin changes was recorded separately for male and female rats on each diet. In the second experiment, an additional group, malnourished from birth for only one generation, was added to the studies of the on-going groups with intergenerational malnutrition and the control group on the adequate intake of protein. A series of post-natally malnourished rats were produced by cross-fostering pups from the well-nourished lineage to mothers from the intergenerationally malnourished group. The pups were transferred at birth, and during suckling, weaning, and onwards, were that allowed access only to the low-protein diet. The frequency of skin lesions in the group compared with the incidence in the intergenerationally malnourished rats and the wellnourished rats of the same generation over a period of 36 months.

\section{Procedure}

Each animal was weighed weekly on a Mettler EI000 automatic balance and carefully inspected for skin lesions. The findings were recorded. When a rat developed a skin lesion, it was kept in an individual galvanized-wire cage for $\mathrm{I}$ week; if the lesion resolved, the rat was replaced in the original cage. If the skin change persisted, the rat was kept in the separate cage and given a supplemental vitamin mix for 2 weeks to address the possibility such changes were secondary to a vitamin deficiency. The supplemental vitamin mix was wasa threefold increase in the amount of the standard vitamin mix (Table I) that was added 
to the drinking-water. All skin lesions were cultured for bacteria, and skin scrapings were examined for ectoparasites. Subjects with persistent skin lesions were killed 2 weeks-2 the months after appearance of a lesion. Postmortem examinations were performed on each animal killed, and tissues were collected for histopathologic evaluation.

\section{Bacteriology}

Crusts were removed aseptically from affected areas, and the underlying ulcerated surface was swabbed with a sterile cotton applicator. The material was then cultured on $50 \mathrm{~g}$ sheep blood/ $\mathrm{kg} \mathrm{MacConkey} \mathrm{agar,} \mathrm{and} \mathrm{mannitol} \mathrm{salt} \mathrm{agar} \mathrm{at} 37^{\circ}$ for $24 \mathrm{~h}$. Similar material placed on Mycosel agar (Scott Laboratories Inc., Fiskeville, R.I.) was incubated at room temperature for I month. When the colony type, cell morphology, and mannitol fermentation of the bacteria were typical of staphylococci, the cultures were screened with a tube coagulase test in which rabbit plasma was used (Bacto Coagulase Plasma; Difco Laboratories, Detroit, Mich.). Coagulase-positive isolates were classified as $S$. aureus, and five isolates were submitted to the Clinical Bacteriology Section, Centre for Disease Control (Atlanta, Ga.) for phage typing. Other bacteria, when present, were identified by standard biochemical techniques.

The skin was randomly cultured from selected animals without lesions in both dietary groups. Because of respiratory disease in the colony, the lungs and nasopharynx of these subjects were also screened for evidence of mycoplasmas and other bacteria.

\section{Experimental infection}

To determine whether skin lesions could be produced experimentally in animals with different nutritional histories, the skin of selected animals was scarified and inoculated with a coagulase-positive $S$. aureus isolate. Four adult rats (two males and two females) and three weanling rats (two males and one female) with histories of protein malnutrition for over fifteen generations, and four rats (two males and two females) with histories of adequateprotein nutrition were used for this study. The inoculum (MIT5Mi13) was cultured from an ulcerative skin lesion on a rat fed on the low-protein diet and was grown in trypticase soy broth (Scott Laboratories) for $18 \mathrm{~h}$ at $37^{\circ}$. Tenfold dilutions were made using sterile distilled water, and $\mathrm{I} \cdot 0 \times 10^{9}$ bacterial colony-forming units $/ \mathrm{ml}$ were used. Test subjects were inoculated with $0.1 \mathrm{ml}$ of this suspension on each test site. Two test sites, one on the right shoulder and one on the right lumbar region, were scarified using a 26-gauge needle and inoculated with the culture of $S$. aureus. Two control sites were similarly scarified on the left shoulder and the left lumbar region and inoculated with the sterile diluent. Observations were made daily for 2 weeks, and the nature of all skin changes was recorded. Subjects were checked again I month after inoculation.

\section{RESULTS}

\section{First series of studies}

Incidence of $\mathrm{S}$. aureus dermatitis. The incidence of dermatitis in rats with histories of many generations of protein malnutrition was studied for 14 months. Skin lesions that lasted at least 2 weeks were found in $10 \%$ (nine of ninety-three animals) of the protein-malnourished rats (Table 2). None of these lesions resolved spontaneously, and the 2 weeks of vitamin supplementation had no effect. All affected subjects in the protein deficient group were parous females; $70 \%$ of all parous females with histories of protein-deficient diet were affected. In contrast, only one of the eighty-seven control subjects had skin lesions that did not resolve spontaneously. (The affected animal was a parous female.) Another parous 
Table 2. Frequency of dermatitis $(\%)$ in rats with intergenerational malnutrition (IGM), post-natal malnutrition (PNM) or on an adequate diet $(C)$

\begin{tabular}{|c|c|c|c|c|}
\hline \multicolumn{5}{|c|}{ (Number of rats/group in parentheses) } \\
\hline $\begin{array}{c}\text { Series of } \\
\text { experiments }\end{array}$ & $\begin{array}{l}\text { Sex of } \\
\text { rat }\end{array}$ & IGM & PNM & C \\
\hline \multirow[t]{2}{*}{ First series } & $\begin{array}{l}\text { o } \\
0\end{array}$ & $\begin{array}{r}26(47) \\
0(26)\end{array}$ & & $\begin{array}{r}12(17) \\
0(19)\end{array}$ \\
\hline & Total & $16(73)$ & & $6(36)$ \\
\hline \multirow[t]{2}{*}{ Second series } & $\begin{array}{l}q \\
0\end{array}$ & $\begin{array}{r}15(75) \\
6(84)\end{array}$ & $\begin{array}{l}3(40) \\
0(49)\end{array}$ & $\begin{array}{l}5(\mathrm{IIO}) \\
0(88)\end{array}$ \\
\hline & Total* & Io (I59) & I (89) & $2(198)$ \\
\hline
\end{tabular}

* Statistical analysis by $\chi^{2}$ test shows that the frequency in the second series is statistically different between IGM, PNM and control animals for combined values of males and females $\left(\chi^{2}=14 \cdot 1, \mathrm{df}=2\right.$, $P=0.004)$.

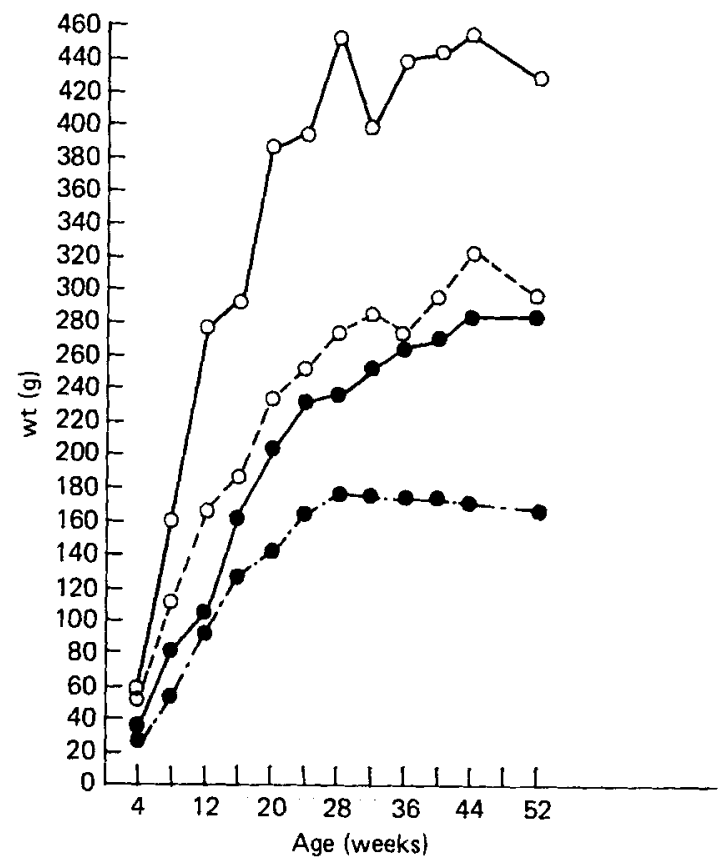

Fig. I. A comparison of weight gains in rats maintained on low-protein $(\boldsymbol{\bullet}, 0,0 ;$

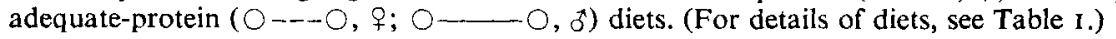

female in the group fed on adequate protein was killed and autopsied I week after the appearance of a skin lesion; thus, it could not be determined whether this lesion would have resolved. The difference in the incidence of lesions between experimental and control animals was significant $\left(\chi^{2} 6 \cdot 2 ; \mathrm{df} I ; P<0.02\right)$.

Four rats (one male and three females) with histories of a protein-deficient diet developed skin lesions that resolved within I week. These rats were all I 6 weeks of age; the females were nulliparous. One male rat from the adequate-protein group, 70 weeks old, was similarly affected.

Fig. I shows the weights of the animals during the test period. Control animals weighed 
more than animals with histories of intergenerational low-protein intake. There was no effect related to sex.

Bacteriologic findings. Skin lesions from eight females on the protein-deficient diet were cultured. Five of these were positive for $S$. aureus, and two of the five isolates were identified as phage types $6 / 53 / 75 / 83 \mathrm{~A} / 84 / 85+$; three were not typable with the available phage types. (The phage types utilized were: $29 / 52 / 52 \mathrm{~A} / 79 / 80 / 3 \mathrm{~A} / 3 \mathrm{C} / 55 / 7 \mathrm{I} / 6 / 42 \mathrm{E} / 47 / 53 / 54 / 75 / 77 /$ $83 \mathrm{~A} / 84 / 8 \mathrm{I} / 94 / 95 / 96$.) In the adequate-protein-diet group, two females with skin lesions and two without were also positive for $S$. aureus. A random sampling of skin flora in the rat colony showed $S$. aureus to be present on animals with and without skin lesions. All cultures for fungus and scrapings for ectoparasites were negative.

S. aureus was also isolated from the lungs of two of eight lesioned rats with histories of protein malnutrition. Mycoplasma pulmonis was isolated from the lungs of another two rats in this group and from one rat in the control group which had no evidence of skin infection.

Necropsy findings. A complete gross and microscopic examination was performed on eight rats with histories of protein malnutrition and on four rats with histories of adequateprotein intake. All protein-deficient animals had skin lesions at the time of necropsy, whereas only two of the animals fed on the adequate diet had skin lesions.

The gross postmortem appearance and location of skin lesions were similar in animals from both dietary groups (Plate I). The lesions occurred primarily on the shoulders and extended to the lateral cervical area and thorax. Similar lesions were found on the thighs, with extension to the dorsolateral lumbar areas. These lesions were characterized grossly by zones of alopecia and brown-crusted material covering moist, rough, red tissue. Affected sites were characterized (Plates 2 and 3 ) by a surface layer of proteinaceous material intermixed with necrotic cellular debris. Acanthosis, focal ulceration, and occasional colonies of coccoid bacteria were present in the epidermis (Plate 4). A cellular infiltrate, composed primarily of polymorphonuclear leukocytes, a few lymphocytes and macrophages, and necrotic cell debris, was present in the dermis. While the histologic changes were similar in all skin lesions, the severity of the lesions varied in individual animals as well as between animals. In some instances, the lesions were limited to changes in the epidermis.

At necropsy, rats from both dietary groups were found to have a similar incidence of consolidation and abscess formation in the lungs. Histopathologic findings were characteristic of chronic respiratory disease caused by $M$. pulmonis. A variety of minor changes in other organs were observed to occur in comparable incidence and magnitude in both dietary groups, including focal mineralization of the kidneys, mild haemosiderosis, extramedullary haematopoiesis and lymphoid hyperplasia of the spleen, and mild haemosiderin deposits in the uterine mucosa. Mild endometritis was present in one affected female rat in the adequate-protein group.

Inoculation study. Experimental inoculation with $S$. aureus produced significant skin changes in subjects with histories of protein deficiency, but no such changes occurred in rats from the adequate-protein group. All adult rats fed on the protein-deficient diet developed a moist ulcerative dermatitis in the shoulder test site that was similar to the lesions previously described. These lesions began with slight erythema and crusting and, by day 5 after inoculation, were ulcerated with serum exudation and crust formation on the exposed skin surface. The lesions were most severe from day 5 to day 10 after inoculation. By 2 weeks the lesions had regressed, and only alopecia was present at the test site. No skin lesions were noted on the sites inoculated with the sterile diluent, except in one female subject that developed an area of erythema, slight serum exudation, and crusting on one of these sites, which healed by $4 \mathrm{~d}$ after inoculation. The three weanling animals from the protein-deficient group developed only mild erythema at the scarified test sites and showed no evidence of infectious dermatitis. The animals with histories of adequate-protein intake 
evidenced only slight reddening of the skin at all four sites, and this disappeared $24 \mathrm{~h}$ after inoculation with no further evidence of skin irritation. All test subjects were examined again I month after experimental inoculation and were found to have no residual evidence of skin lesions.

\section{Second series of studies}

Since the first series dealt only with rats malnourished for many generations, it seemed desirable to determine whether protein deficiency for a single generation would be sufficient to cause these lesions to occur as frequently. Accordingly, the second series of observations was made on rats born to well-nourished mothers but cross-fostered to lactating dams belonging to the intergenerationally malnourished series; these pups continued to receive the low-protein diet for the rest of their lives. The incidence of dermatitis in this group was compared with those in the control group and the intergenerationally malnourished group. Table 2 shows that, over the four generations since the first experiment, dermatitis among the intergenerationally malnourished animals was $15 \%$ for females and $6 \%$ for males, compared with 5 and $0 \%$, respectively, for animals receiving the adequate intake of protein. Female and male rats malnourished post-natally for a single generation showed as few cases of dermatitis ( $3 \%$ for the females and $0 \%$ for the males) as did the control animals. Because the numbers of rats with dermatitis in each group of males was so low, we aggregated males and females for statistical purposes. A $\chi^{2}$ analysis was performed on these combined data (Table 2) and showed high significance as a result of the greater frequency of dermatitis in the intergenerationally malnourished animals.

The second study shows that the continued maintenance of the colony resulted in dermatitis in both males and females of the intergenerationally malnourished group. The incidence of dermatitis was lower for both intergenerationally malnourished and control animals in the second series. However, the relative frequency remained similar. Further, in both series female rats were much more frequently affected than males (Table 2). Post-natal malnutrition was not associated with any increased incidence of dermatitis, even though the post-natal malnutrition used was quite severe, since the pups were suckled by a dam who came from a stock that had been malnourished for generations. It should be noted that investigations of micro-organisms associated with the dermatitis were not carried out in the second series of studies.

\section{DISCUSSION}

In the first series of studies, rats with histories of many generations of protein malnutrition were found to be at higher risk for the development of dermatitis with $S$. aureus infection than were rats in the same colony maintained on a diet with adequate protein. Moreover, experimental dermatitis from $S$. aureus inoculation appeared only in rats from the proteindeficient-diet group, even though $S$. aureus was present on the skins of both malnourished and control groups. This implies that resistance to this organism is lowered by intergenerational malnutrition.

There are several possible explanations. First, the integrity of the skin is a major factor in preventing infection. A low-protein diet has been reported to impair cross-linking and maturation of collagen in rats (Prasad \& Bose, 1974), which results in increased skin friability. Increased skin friability and thin coats have been observed in protein-deficient subjects in this experimental colony (Stewart, I972). Such friability of the skin may predispose animals to trauma, secondary infection, and to delayed wound healing.

Second, the high incidence of dermatitis in the protein-malnourished group may alsc be a consequence of reduced ability to produce antibodies. In rats, protein deficiency has known depressant effects on antibody-forming cells of both immunoglobulin classes and haemolysin titres (Chandra, 1975). Such impaired immunocompetence is, therefore, highly 
probable in a group of animals with chronic protein malnutrition and may predispose them to bacterial infection.

Third, it must be recognized that rats fed on a low-protein diet are likely to decrease their total food intake, so that a combined deficiency may result. In the present study, vitamin supplementation did not ameliorate the dermatitis in affected subjects. Selected supplementation with fatty acids and trace elements, particularly zinc, was not undertaken, although deficiencies in these items have been implicated in rodent dermatosis (Quarterman, 1967).

It is not clear from these results whether $S$. aureus was the primary cause of the dermatitis, or whether nutritional factors were responsible for a dermatitis with a secondary infection with $S$. aureus. $S$. aureus is a ubiquitous organism that has been implicated in other reports of rat dermatosis (Blackmore \& Francis, 1970; Ash, 1971).

Finally, in the second series of studies, comparison of a single period of post-natal malnutrition with intergenerational malnutrition indicates that deficiency of protein for several generations increases susceptibility to dermatitis in female and male rats. Among the male rats, only those with intergenerational malnutrition developed skin lesions. These findings thus demonstrate that malnutrition over several generations has a cumulative effect and is, consequently, of potential importance for human populations chronically exposed to protein-energy malnutrition.

Dr Galler is a Fellow of the Medical Foundation, Boston, Massachusetts and was supported by funds made available through the Grant Foundation, the Ford Foundation, and the National Science Foundation (BNS-76-10222).

The authors would like to thank Ms Marlene Rosenthal for her technical assistance, and Dr P. B. Smith, Chief of the Clinical Bacteriology Section, Bacteriology Branch, Center for Disease Control, Atlanta, GA, for phage typing.

\section{REFERENCES}

Ash, G. W. (1971). Lab. Anim. 5, I15.

Blackmore, D. K. \& Francis, R. A. (1970). J. comp. Path. Therap. 80, 645.

Chandra, R. K. (1975). Science N.Y. rgo, 289.

Follis, R. H. (1958). Deficiency Disease. Springfield, Ill.: C. C. Thomas.

Jelinck, V. (1967). In Husbandry of Laboratory Animals, p. 97 [M. L. Connalty, editor]. New York: Academic Press.

Oldham, J. N. ( 1967 ). In Pathology of Laboratory Rats and Mice, p. 641 [E. Cotchin \& F. J. C. Roe, editors]. Oxford: Blackwell Scientific Publications.

Payne, P. R. \& Stewart, R. J. C. (1972). Lab. Anim. 6, 135.

Prasad, C. U. \& Bose, S. N. (1974). Nutr. Metab. 16, 1972.

Quaterman, J. (1967). In Husbandry of Laboratory Animals, p. 115 [M. L. Connalty, editor]. New York: Academic Press.

Rogers, R. Q. \& Harper, A. E. (1965). J. Nutr. 87, 267.

Scrimshaw, N. S. (1975). Progr. Fd. Nutr. Sci. r, 393.

Stewart, R. J. C. (1972). In Nutrition, the Nervous System and Behavior, p. 33. New York: Pan American Health Organization.

Van Rooyen, C. R. (1936). J. Path. Bact. 43, 455.

\section{EXPLANATION OF PLATES}

Plate I. Skin lesions with alopecia and scab formation distributed over the lateral cervical area, shoulder, and thorax of the rat. Rats maintained on either low-protein or adequate-protein diet (for details of diets, see Table I) showed similar lesions.

Plate 2. View of skin lesions showing focal ulceration of the epidermis and eschar formation of the rat. Rats maintained on either low-protein or adequate-protein diet (for details of diets, see Table 1 ) showed similar lesions. (H \& E stain; $\times 80$ ) 
Plate 3. Magnified view of Jesion showing ulceration of the epidermis, necrotic cellular debris, eschar, and cellular infiltration of the dermis of the rat. Rats maintained on either low-protein or adequate-protein diet (for details of diets, see Tabie I) showed similar lesions. (H \& E stain; $\times 200$ )

Plate 4. Ulcerated skin lesion with multiple aggregates of coccoid bacteria at the tissue-eschar interface of the rat. Rats maintained on either low-protein or adequate-protein diet (for details of diets, see Table I) showed similar lesions. (H \& E stain; $\times 360$ ) 
British Journal of Nutrition, Vol. 4I, No. 3

Plate I

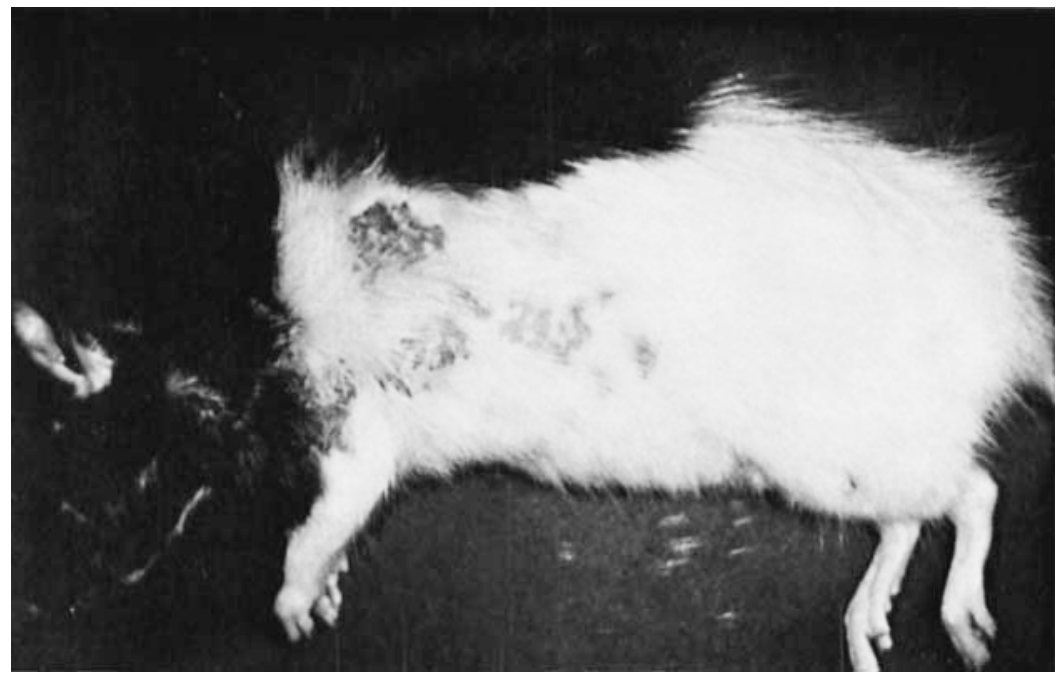




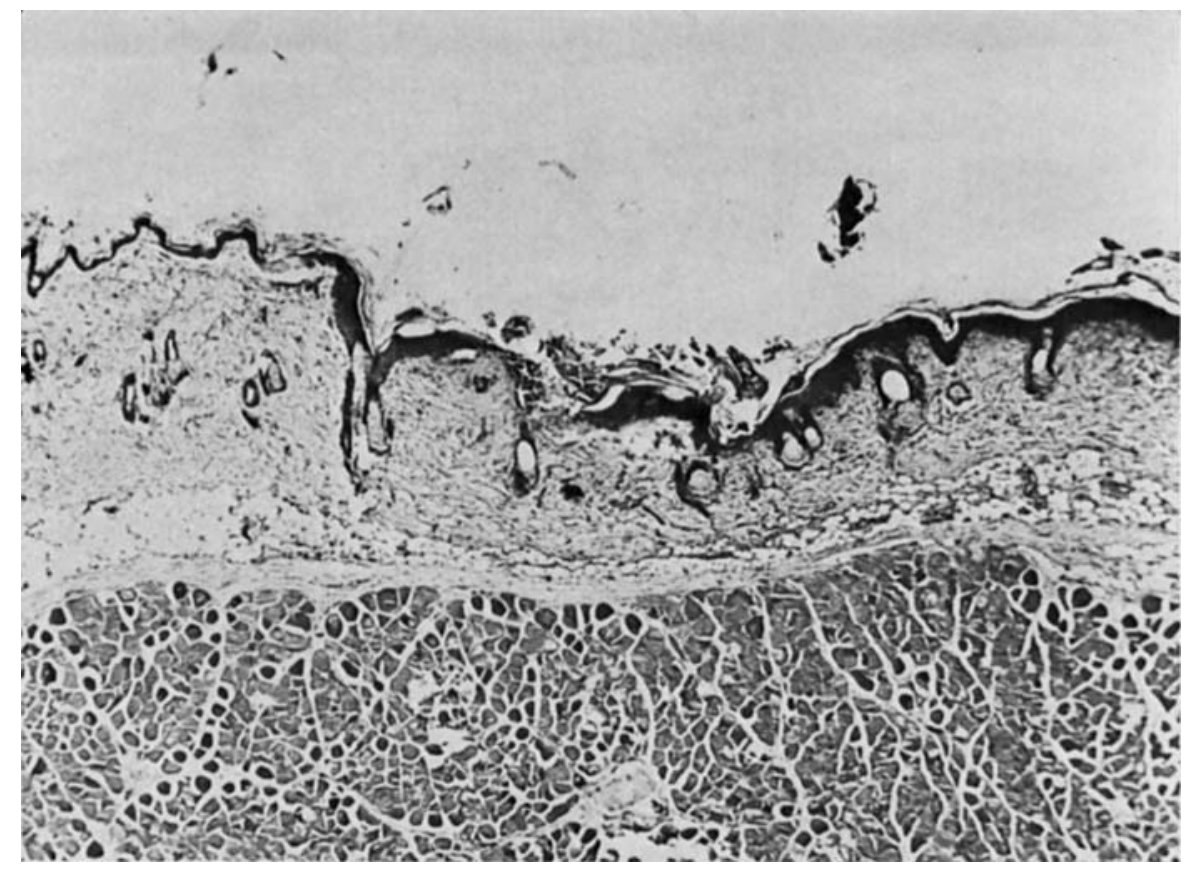




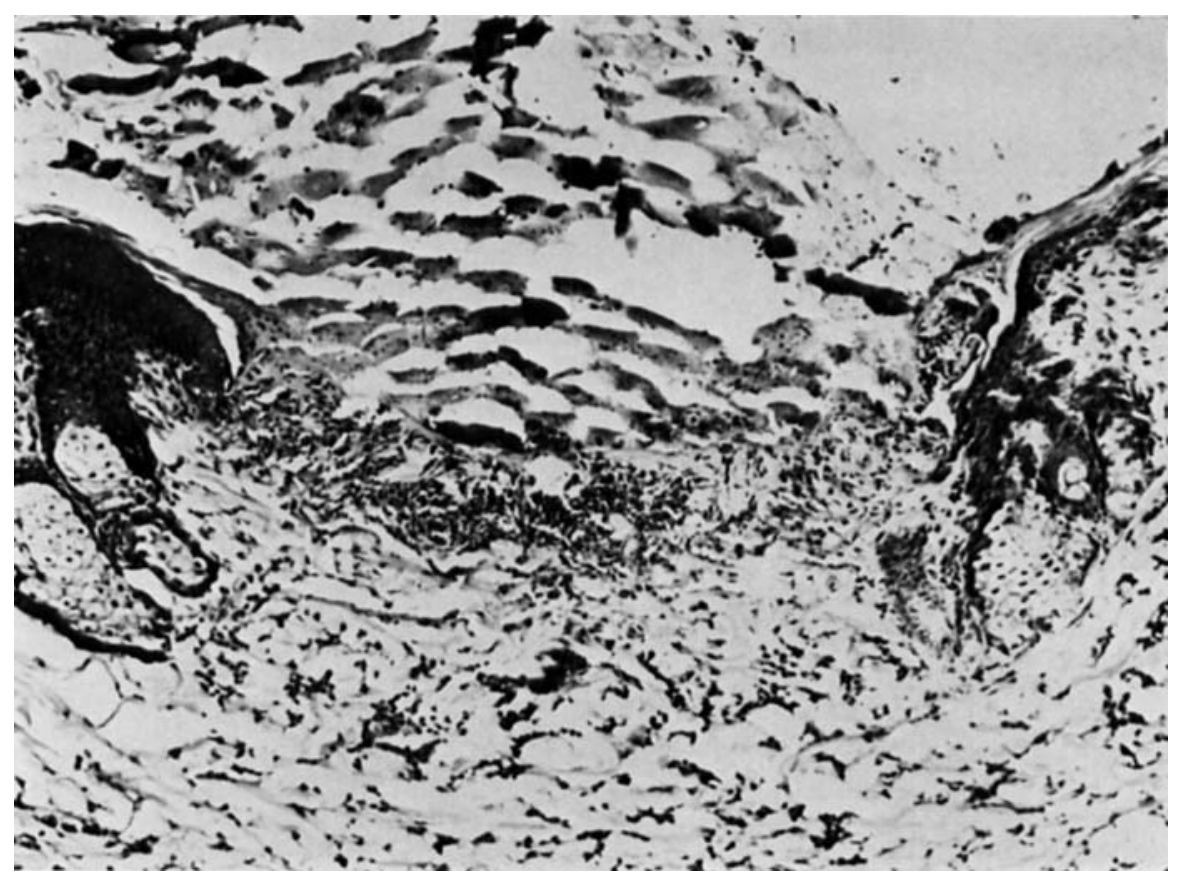




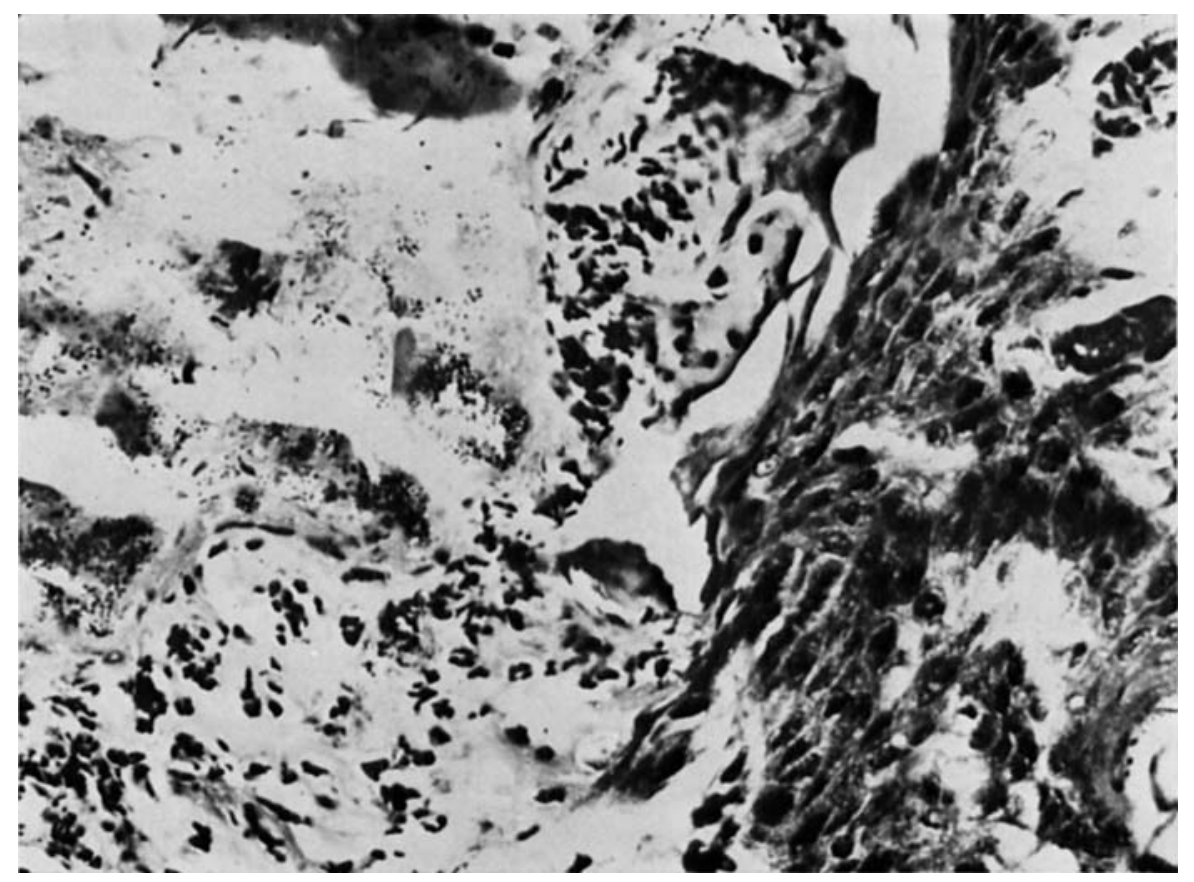

